Supplement of E\&G Quaternary Sci. J., 69, 61-87, 2020

https://doi.org/10.5194/egqsj-69-61-2020-supplement

(C) Author(s) 2020. This work is distributed under

the Creative Commons Attribution 4.0 License.

(c) (1)

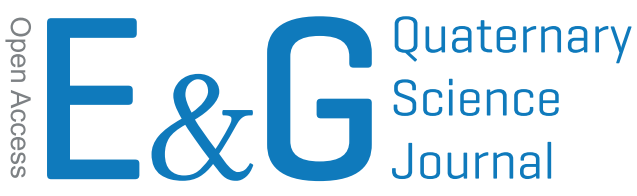

Supplement of

\title{
Revisiting Late Pleistocene glacier dynamics north-west of the Feldberg, southern Black Forest, Germany
}

Felix Martin Hofmann et al.

Correspondence to: Felix Martin Hofmann (felix.martin.hofmann@geologie.uni-freiburg.de)

The copyright of individual parts of the supplement might differ from the CC BY 4.0 License. 
Table S1: Ice-marginal positions in Sankt Wilhelmer Tal

\begin{tabular}{|c|c|c|c|c|}
\hline $\begin{array}{l}\text { Ice- } \\
\text { marginal } \\
\text { position } \\
\text { (this } \\
\text { study) }\end{array}$ & $\begin{array}{l}\text { Location } \\
\text { of } \\
\text { terminal } \\
\text { moraines } \\
\text { (m } \\
\text { a.s.l.) }\end{array}$ & $\begin{array}{l}\text { Original } \\
\text { reference }\end{array}$ & Description & $\begin{array}{l}\text { Interpretation } \\
\text { or comment } \\
\text { (this study) }\end{array}$ \\
\hline 1 & 1030 & - & $\begin{array}{l}\text { ESE-WNW oriented sediment } \\
\text { ridge on the eastern headwall of } \\
\text { the Napf cirque }\end{array}$ & $\begin{array}{l}\text { Terminal } \\
\text { moraine }\end{array}$ \\
\hline - & 985 & Zienert (1973) & $\begin{array}{l}\text { Ridge on the eastern headwall of } \\
\text { the cirque }\end{array}$ & $\begin{array}{l}\text { Not identified } \\
\text { in this study }\end{array}$ \\
\hline $2 \& 3$ & 910 & $\begin{array}{l}\text { Schreiner } \\
(1977 \mathrm{~b})\end{array}$ & $\begin{array}{l}\text { Two-crested sediment ridge with } \\
\text { a steep northern flank and a } \\
\text { gently sloping southern side; on } \\
\text { the valley floor }\end{array}$ & $\begin{array}{l}\text { Terminal } \\
\text { moraine }\end{array}$ \\
\hline - & 850 & Klute (1911) & $\begin{array}{l}\text { Terrace-shaped accumulation of } \\
\text { partly rounded boulders on the } \\
\text { valley floor }\end{array}$ & $\begin{array}{l}\text { Rockslide } \\
\text { deposit }\end{array}$ \\
\hline 4 & 820 & - & $\begin{array}{l}\text { E-W oriented, subdued sediment } \\
\text { ridge on the northern valley side }\end{array}$ & $\begin{array}{l}\text { Terminal } \\
\text { moraine }\end{array}$ \\
\hline 5 & 820 & - & $\begin{array}{l}\text { E-W oriented, subdued sediment } \\
\text { ridge on the northern valley side }\end{array}$ & $\begin{array}{l}\text { Terminal } \\
\text { moraine }\end{array}$ \\
\hline 6 & 820 & - & $\begin{array}{l}\text { SE-NW oriented ridge composed } \\
\text { of boulders on the southern } \\
\text { valley side }\end{array}$ & $\begin{array}{l}\text { Terminal } \\
\text { moraine }\end{array}$ \\
\hline 7 & 780 & $\begin{array}{l}\text { Schreiner } \\
(1977 b)\end{array}$ & $\begin{array}{l}\text { NE-SW oriented sediment ridge } \\
\text { (oriented perpendicular to the } \\
\text { orientation of the valley); on the } \\
\text { valley floor }\end{array}$ & $\begin{array}{l}\text { Terminal } \\
\text { moraine }\end{array}$ \\
\hline
\end{tabular}




\begin{tabular}{|c|c|c|c|c|}
\hline 8 & 780 & $\begin{array}{l}\text { Schreiner } \\
(1977 b)\end{array}$ & $\begin{array}{l}\text { NE-SW oriented sediment ridge } \\
\text { (oriented perpendicular to the } \\
\text { orientation of the valley); on the } \\
\text { valley floor }\end{array}$ & $\begin{array}{l}\text { Terminal } \\
\text { moraine }\end{array}$ \\
\hline 9 & 780 & - & $\begin{array}{l}\text { Arc-shaped sediment ridge on } \\
\text { the valley floor }\end{array}$ & $\begin{array}{l}\text { Terminal } \\
\text { moraine }\end{array}$ \\
\hline 10 & 780 & - & $\begin{array}{l}\text { Arc-shaped sediment ridge on } \\
\text { the valley floor }\end{array}$ & $\begin{array}{l}\text { Terminal } \\
\text { moraine }\end{array}$ \\
\hline $11 \& 12$ & $700-760$ & $\begin{array}{l}\text { Schreiner } \\
(1977 b)\end{array}$ & $\begin{array}{l}\text { Two-crested sediment ridge with } \\
\text { a SE-NW orientation on the } \\
\text { valley floor }\end{array}$ & $\begin{array}{l}\text { Terminal } \\
\text { moraine }\end{array}$ \\
\hline 13 & 700 & Klute (1911) & $\begin{array}{l}\text { SW-NE oriented sediment ridge } \\
\text { with a steep NW side and a } \\
\text { gently sloping SE flank; on the } \\
\text { valley floor }\end{array}$ & $\begin{array}{l}\text { Terminal } \\
\text { moraine }\end{array}$ \\
\hline 14 & 900 & - & $\begin{array}{l}\text { Arc-shaped sediment ridge with } \\
\text { a strongly asymmetric cross- } \\
\text { section (steep NE flank and } \\
\text { gently sloping SW side); } \\
\text { separated from the surrounding } \\
\text { slope by a depression; on the } \\
\text { southern valley side }\end{array}$ & $\begin{array}{l}\text { Terminal } \\
\text { moraine }\end{array}$ \\
\hline 15 & 910 & - & $\begin{array}{l}\text { NW-SE oriented sediment ridge } \\
\text { with a steep NE side; separated } \\
\text { from the surrounding slope by a } \\
\text { depression; on the southern } \\
\text { valley side }\end{array}$ & $\begin{array}{l}\text { Terminal } \\
\text { moraine }\end{array}$ \\
\hline
\end{tabular}




\begin{tabular}{|l|l|l|l|l|}
\hline 16 & 920 & - & $\begin{array}{l}\text { NW-SE oriented sediment ridge } \\
\text { with a steep NE side; separated } \\
\text { from the surrounding slope by a } \\
\text { depression; on the southern } \\
\text { valley side }\end{array}$ & $\begin{array}{l}\text { Terminal } \\
\text { moraine }\end{array}$ \\
\hline 17 & 930 & - & $\begin{array}{l}\text { NW-SE oriented sediment ridge } \\
\text { with a steep NE side; separated } \\
\text { from the surrounding slope by a } \\
\text { depression; on the southern } \\
\text { valley side }\end{array}$ & $\begin{array}{l}\text { Terminal } \\
\text { moraine }\end{array}$ \\
\hline 18 & 650 & Hüttner (1967) & $\begin{array}{l}\text { Terrace-shaped accumulation of } \\
\text { partly rounded boulders on the } \\
\text { valley floor }\end{array}$ & $\begin{array}{l}\text { Medial } \\
\text { moraine }\end{array}$ \\
\hline
\end{tabular}


Table S2: Ice-marginal positions in the Wittenbach cirque

\begin{tabular}{|c|c|c|c|c|}
\hline $\begin{array}{l}\text { Ice- } \\
\text { marginal } \\
\text { position } \\
\text { (this } \\
\text { study) }\end{array}$ & $\begin{array}{l}\text { Location } \\
\text { of } \\
\text { terminal } \\
\text { moraines } \\
\text { (m a.s.l.) }\end{array}$ & $\begin{array}{l}\text { Original } \\
\text { reference }\end{array}$ & Description & $\begin{array}{l}\text { Interpretation } \\
\text { or comment } \\
\text { (this study) }\end{array}$ \\
\hline 1 & 1210 & - & $\begin{array}{l}\text { N-S oriented, arc shaped } \\
\text { sediment ridge in the SE corner } \\
\text { of the cirque }\end{array}$ & $\begin{array}{l}\text { Terminal } \\
\text { moraine }\end{array}$ \\
\hline 2 & 1170 & - & $\begin{array}{l}\text { SW-NE oriented, arc shaped } \\
\text { sediment ridge at the margin of } \\
\text { the uppermost cirque floor }\end{array}$ & $\begin{array}{l}\text { Terminal } \\
\text { moraine }\end{array}$ \\
\hline - & 1120 & $\begin{array}{l}\text { Schreiner } \\
(1977 \mathrm{~b})\end{array}$ & $\begin{array}{l}\text { Arc shaped ridge at the northern } \\
\text { end of the intermediate cirque } \\
\text { floor }\end{array}$ & $\begin{array}{l}\text { Not identified } \\
\text { in this study }\end{array}$ \\
\hline 3 & 1100 & - & $\begin{array}{l}\text { N-S oriented sediment ridge NE } \\
\text { of the intermediate cirque floor }\end{array}$ & $\begin{array}{l}\text { Terminal } \\
\text { moraine }\end{array}$ \\
\hline 4 & 1100 & - & $\begin{array}{l}\text { Sediment ridges NE and NW of } \\
\text { the intermediate cirque floor }\end{array}$ & $\begin{array}{l}\text { Terminal } \\
\text { moraine }\end{array}$ \\
\hline 5 & 990 & $\begin{array}{l}\text { Schreiner } \\
(1977 b)\end{array}$ & $\begin{array}{l}\text { Arc shaped sediment ridge with } \\
\text { a smooth crest on the lowermost } \\
\text { cirque floor }\end{array}$ & $\begin{array}{l}\text { Overprinted } \\
\text { terminal } \\
\text { moraine }\end{array}$ \\
\hline 6 & 980 & $\begin{array}{l}\text { Schreiner } \\
(1977 b)\end{array}$ & $\begin{array}{l}\text { Arc shaped sediment ridge with } \\
\text { a smooth crest on the lowermost } \\
\text { cirque floor }\end{array}$ & $\begin{array}{l}\text { Overprinted } \\
\text { terminal } \\
\text { moraine }\end{array}$ \\
\hline 7 & 950 & $\begin{array}{l}\text { Schreiner } \\
(1977 b)\end{array}$ & $\begin{array}{l}\text { Arc shaped sediment ridge with } \\
\text { a smooth crest on the lowermost } \\
\text { cirque floor }\end{array}$ & $\begin{array}{l}\text { Overprinted } \\
\text { terminal } \\
\text { moraine }\end{array}$ \\
\hline
\end{tabular}




\begin{tabular}{|l|l|l|l|l|}
\hline 8 & 860 & Klute (1911) & $\begin{array}{l}\text { Sediment ridge at the entrance } \\
\text { to the cirque extending up to } \\
\text { the eastern headwall of the } \\
\text { cirque }\end{array}$ & $\begin{array}{l}\text { Terminal } \\
\text { moraine }\end{array}$ \\
& & & \\
\hline
\end{tabular}


Table S3: Ice-marginal positions in the Katzensteig cirque

\begin{tabular}{|c|c|c|c|c|}
\hline $\begin{array}{l}\text { Ice- } \\
\text { marginal } \\
\text { position } \\
\text { (this } \\
\text { study) }\end{array}$ & $\begin{array}{l}\text { Location } \\
\text { of } \\
\text { terminal } \\
\text { moraines } \\
\text { (m a.s.l.) }\end{array}$ & $\begin{array}{l}\text { Original } \\
\text { reference }\end{array}$ & Description & $\begin{array}{l}\text { Interpretation } \\
\text { or comment } \\
\text { (this study) }\end{array}$ \\
\hline 1 & $\begin{array}{l}1040 \\
1080\end{array}$ & $\begin{array}{l}\text { Schreiner } \\
(1977 b)\end{array}$ & $\begin{array}{l}\text { W-E oriented, asymmetric } \\
\text { sediment ridges }\end{array}$ & $\begin{array}{l}\text { Terminal } \\
\text { moraine }\end{array}$ \\
\hline 2 & $\begin{array}{l}1020 \\
1030\end{array}$ & Klute (1911) & $\begin{array}{l}\text { SW-NE to W-E oriented, } \\
\text { asymmetric sediment ridges; } \\
\text { partly separated from the } \\
\text { surrounding slope }\end{array}$ & $\begin{array}{l}\text { Terminal } \\
\text { moraine }\end{array}$ \\
\hline 3 & 1020 & Klute (1911) & $\begin{array}{l}\text { W-E oriented, asymmetric } \\
\text { sediment ridges; partly } \\
\text { separated from the surrounding } \\
\text { slope }\end{array}$ & $\begin{array}{l}\text { Terminal } \\
\text { moraine }\end{array}$ \\
\hline 4 & $\begin{array}{l}900 ; 980 ; \\
1030\end{array}$ & $\begin{array}{l}\text { Schreiner } \\
(1977 b)\end{array}$ & $\begin{array}{l}\text { SW-NE and N-S oriented, } \\
\text { asymmetric sediment ridges; } \\
\text { separated from the surrounding } \\
\text { slope }\end{array}$ & $\begin{array}{l}\text { Terminal } \\
\text { moraine }\end{array}$ \\
\hline 5 & $\begin{array}{l}890 ; 980 ; \\
1060\end{array}$ & $\begin{array}{l}\text { Schreiner } \\
(1977 b)\end{array}$ & $\begin{array}{l}\text { N-S and SW-NE oriented, } \\
\text { asymmetric sediment ridges; not } \\
\text { separated from the surrounding } \\
\text { slope }\end{array}$ & $\begin{array}{l}\text { Terminal } \\
\text { moraine }\end{array}$ \\
\hline 6 & $890 ; 1110$ & - & $\begin{array}{l}\text { Arc-shaped, asymmetric } \\
\text { sediment ridge on the eastern } \\
\text { headwall of the cirque and SW- } \\
\text { NE oriented sediment ridge } \\
\text { north of the entrance to the } \\
\text { cirque }\end{array}$ & $\begin{array}{l}\text { Terminal } \\
\text { moraine }\end{array}$ \\
\hline
\end{tabular}




\begin{tabular}{|l|l|l|l|l|}
\hline 7 & 1110 & - & $\begin{array}{l}\text { Arc-shaped, asymmetric } \\
\text { sediment ridge on the eastern } \\
\text { headwall of the cirque }\end{array}$ & $\begin{array}{l}\text { Terminal } \\
\text { moraine }\end{array}$ \\
\hline
\end{tabular}


Table S4: Ice-marginal positions in Zastler Tal

\begin{tabular}{|c|c|c|c|c|}
\hline $\begin{array}{l}\text { Ice- } \\
\text { marginal } \\
\text { position } \\
\text { (this } \\
\text { study) }\end{array}$ & $\begin{array}{l}\text { Location } \\
\text { of } \\
\text { terminal } \\
\text { moraines } \\
\text { (m a.s.l.) }\end{array}$ & $\begin{array}{l}\text { Original } \\
\text { reference }\end{array}$ & Description & $\begin{array}{l}\text { Interpretation } \\
\text { or comment } \\
\text { (this study) }\end{array}$ \\
\hline \multirow[t]{2}{*}{1} & $\begin{array}{l}1400- \\
1420\end{array}$ & - & $\begin{array}{l}\text { Set of short sediment ridges on } \\
\text { the uppermost cirque floor }\end{array}$ & $\begin{array}{l}\text { Terminal } \\
\text { moraine }\end{array}$ \\
\hline & $\begin{array}{l}1340- \\
1360\end{array}$ & Zienert (1973) & $\begin{array}{l}\text { Set of sediment ridges in the SE } \\
\text { corner of the cirque }\end{array}$ & $\begin{array}{l}\text { Terminal } \\
\text { moraine }\end{array}$ \\
\hline \multirow[t]{2}{*}{2} & $\begin{array}{l}1400- \\
1430\end{array}$ & - & $\begin{array}{l}\text { Arcuate sediment ridge at the } \\
\mathrm{NW} \text { margin of the uppermost } \\
\text { cirque floor }\end{array}$ & $\begin{array}{l}\text { Terminal } \\
\text { moraine }\end{array}$ \\
\hline & $\begin{array}{l}1320- \\
1340\end{array}$ & Zienert (1973) & $\begin{array}{l}\text { Set of sediment ridges in the SE } \\
\text { corner of the cirque }\end{array}$ & $\begin{array}{l}\text { Terminal } \\
\text { moraine }\end{array}$ \\
\hline 3 & $\begin{array}{l}1340- \\
1350\end{array}$ & - & $\begin{array}{l}\text { Sediment ridges with a SW-NE } \\
\text { and a SE-NW orientation in the } \\
\text { SE corner of the cirque }\end{array}$ & $\begin{array}{l}\text { Terminal } \\
\text { moraine }\end{array}$ \\
\hline 4 & 1260 & $\begin{array}{l}\text { Steinmann } \\
(1902)\end{array}$ & $\begin{array}{l}\text { Arcuate sediment ridge } \\
\text { separated from the eastern } \\
\text { headwall of the cirque by a } \\
\text { depression; at the margin of the } \\
\text { lowermost cirque floor }\end{array}$ & $\begin{array}{l}\text { Terminal } \\
\text { moraine }\end{array}$ \\
\hline 5 & 1270 & $\begin{array}{l}\text { Schreiner } \\
(1981)\end{array}$ & $\begin{array}{l}\text { Arcuate sediment ridge on the } \\
\text { eastern headwall of the cirque }\end{array}$ & $\begin{array}{l}\text { Terminal } \\
\text { moraine }\end{array}$ \\
\hline
\end{tabular}




\begin{tabular}{|c|c|c|c|c|}
\hline 6 & $\begin{array}{l}1200- \\
1290\end{array}$ & $\begin{array}{l}\text { Schreiner } \\
(1981)\end{array}$ & $\begin{array}{l}\text { Two SE-NE oriented sediment } \\
\text { ridges on the eastern headwall of } \\
\text { the cirque, a S-N oriented } \\
\text { sediment ridge on the centre of } \\
\text { the valley and a S-N oriented } \\
\text { sediment ridge on the western } \\
\text { headwall of the cirque }\end{array}$ & $\begin{array}{l}\text { Terminal } \\
\text { moraine }\end{array}$ \\
\hline 7 & 1200 & $\begin{array}{l}\text { Schreiner } \\
(1981)\end{array}$ & $\begin{array}{l}\text { S-N oriented sediment ridge on } \\
\text { the eastern headwall of the } \\
\text { cirque }\end{array}$ & $\begin{array}{l}\text { Terminal } \\
\text { moraine }\end{array}$ \\
\hline $8 \& 9$ & 1030 & $\begin{array}{l}\text { Steinmann } \\
(1902)\end{array}$ & $\begin{array}{l}\text { Two-crested, arcuate sediment } \\
\text { ridge on the centre of the valley } \\
\text { floor }\end{array}$ & $\begin{array}{l}\text { Terminal } \\
\text { moraine }\end{array}$ \\
\hline 10 & 980 & - & $\begin{array}{l}\text { Short sediment ridge on the } \\
\text { centre of the valley floor }\end{array}$ & $\begin{array}{l}\text { Terminal } \\
\text { moraine }\end{array}$ \\
\hline 11 & 970 & - & $\begin{array}{l}\text { Short sediment ridge on the } \\
\text { centre of the valley floor }\end{array}$ & $\begin{array}{l}\text { Terminal } \\
\text { moraine }\end{array}$ \\
\hline 12 & 970 & - & $\begin{array}{l}\text { SE-NE oriented sediment ridge } \\
\text { on the western valley side }\end{array}$ & $\begin{array}{l}\text { Terminal } \\
\text { moraine }\end{array}$ \\
\hline 13 & 980 & - & $\begin{array}{l}\text { SE-NE oriented sediment ridge } \\
\text { on the western valley side }\end{array}$ & $\begin{array}{l}\text { Terminal } \\
\text { moraine }\end{array}$ \\
\hline- & 860 & Zienert (1973) & $\begin{array}{l}\text { Ridge on the centre of the valley } \\
\text { floor }\end{array}$ & $\begin{array}{l}\text { Not identified } \\
\text { in this study }\end{array}$ \\
\hline 14 & 720 & - & $\begin{array}{l}\text { Small sediment ridge on the } \\
\text { centre of the valley floor }\end{array}$ & $\begin{array}{l}\text { Terminal } \\
\text { moraine }\end{array}$ \\
\hline - & 720 & $\begin{array}{l}\text { Steinmann } \\
(1910)\end{array}$ & $\begin{array}{l}\text { Prominent ridge oriented } \\
\text { perpendicular to the valley floor }\end{array}$ & Riegel \\
\hline 15 & 640 & $\begin{array}{l}\text { Schreiner } \\
(1977 \mathrm{a})\end{array}$ & $\begin{array}{l}\text { Arcuate sediment ridge on the } \\
\text { valley floor }\end{array}$ & $\begin{array}{l}\text { Terminal } \\
\text { moraine }\end{array}$ \\
\hline
\end{tabular}




\begin{tabular}{|l|l|l|l|l|}
\hline 940 & $\begin{array}{l}\text { Schreiner } \\
(1977 \mathrm{a})\end{array}$ & $\begin{array}{l}\text { Ridge-shaped accumulation of } \\
\text { boulders parallel to the valley } \\
\text { floor; on the southern valley side } \\
\text { south of Schweizerhof }\end{array}$ & $\begin{array}{l}\text { Terminal } \\
\text { moraine }\end{array}$ \\
\hline 16 & 620 & Zienert (1973) & $\begin{array}{l}\text { Arcuate sediment ridge on the } \\
\text { valley floor and both valley sides }\end{array}$ & $\begin{array}{l}\text { Terminal } \\
\text { moraine }\end{array}$ \\
\hline $770-780$ & Hüttner (1967) & $\begin{array}{l}\text { Ridge-shaped accumulation of } \\
\text { boulders parallel to the valley } \\
\text { floor; on the southern valley side } \\
\text { between the entrance to } \\
\text { Stollenbach and Angelsbach }\end{array}$ & $\begin{array}{l}\text { Terminal } \\
\text { moraine }\end{array}$ \\
\hline 17 & 560 & Erb (1948) & $\begin{array}{l}\text { Short sediment ridge on the } \\
\text { southern and the northern valley } \\
\text { side near Jockelehof }\end{array}$ & $\begin{array}{l}\text { Terminal } \\
\text { moraine }\end{array}$ \\
\hline 550 & Erb (1948) & $\begin{array}{l}\text { Short sediment ridge on the } \\
\text { southern and the northern valley } \\
\text { side near Jockelehof }\end{array}$ & $\begin{array}{l}\text { Terminal } \\
\text { moraine }\end{array}$ \\
\hline
\end{tabular}




\section{Establishment of the digital surface model of the upper Katzensteig}

Due to the presence of well-preserved terminal moraines, the rugged terrain and the lack of vegetation, an additional drone survey was conducted in the Katzensteig valley to derive a more precise digital surface model (DSM) based on structure-from motion photogrammetry (Westoby et al., 2012). 470 photos of the unforested area in the upper Katzensteig were obtained using a DJI Mavic quadrocopter equipped with a FC220 camera (12 megapixel). The internal GPS of the quadrocopter enabled the coordinates of the locations from which the photos were taken to be recorded. The photos were subsequently imported in Agisoft Photoscan. The photos were first aligned using the highest quality setting. The application of the 'dense point cloud' command resulted in the identification of c. 540,000,000 points, whereby the ultra-high-quality setting was chosen. A mesh was subsequently created from the dense point cloud using the 'height field' mode. Lastly, an orthomosaic and a DSM were derived from the mesh and dense point cloud, respectively. The orthophoto has a $\mathrm{x}$ - and y-cell size of 5.4 and $3.7 \mathrm{~cm}$, respectively, whereas the DSM has a pixel size of $3.7 \mathrm{~cm}$. Due to the sheltered location of Katzensteig, the total error of the georeferencing was $2.67 \mathrm{~m}$. Due to this high error with respect to the pixel size of the DSM, the DSM and an existing DTM of the area were compared. Since the DSM and the DTM agreed well, the georeferencing error of the DSM was deemed acceptable. To correct the DSM for trees, trees were digitised in ArcMap. The resulting shapefile was then substracted from the DEM using the 'clip' tool. The application of the 'Elevation void fill function' enabled the substracted areas to be filled. 


\section{References}

Erb, L.: Die Geologie des Feldbergs, in: Der Feldberg im Schwarzwald, edited by: Müller, K., L. Bielefelds Verlag KG, Freiburg i. Br., 22-96, 1948.

Hüttner, R.: Das Quartär, in: Geologische Karte von Baden-Württemberg 1:25 000, Erläuterungen zu Blatt 8013 Freiburg-Südost, edited by: Geologisches Landesamt Baden-Württemberg, Landesvermessungsamt Baden-Württemberg, Stuttgart, 69-105, 1967.

Klute, F.: Die Schneereste des Schwarzwaldes im Frühsommer und die Beziehungen ihrer Lage zu den Stellen ehemaliger Vergletscherung, Ber. Naturf. Ges. Freiburg i. Br., 19, 61-116, 1911.

Schreiner, A.: Geologische Karte von Freiburg i. Br. und Umgebung 1:50000, 1st ed., Geologisches Landesamt Baden-Württemberg, Freiburg i. Br., 1977a.

Schreiner, A.: Quartär, in: Erläuterungen zur Geologischen Karte von Freiburg i. Br. und Umgebung 1:50 000, 1st ed., edited by: Geologisches Landesamt Baden-Württemberg, Landesvermessungsamt Baden-Württemberg, Stuttgart, 174-198, 1977b.

Schreiner, A.: Quartär, in: Geologische Karte von Baden-Württemberg 1:25 000. Erläuterungen zu Blatt 8114 Feldberg, 1st ed., edited by: Geologisches Landesamt Baden-Württemberg, Landesvermessungsamt Baden-Württemberg, Stuttgart, 67-95, 1981.

Steinmann, G.: Die Bildungen der letzten Eiszeit im Bereiche des alten Wutachgebiets, Ber. d. Oberrhein. Geol. Ver., 35, 1-8, 1902.

Steinmann, G.: Die Eiszeit und der vorgeschichtliche Mensch, Aus Natur und Geisteswelt, 302, B. G. Teubner, Leipzig, 1910.

Westoby, M. J., Brasington, J., Glasser, N. F., Hambrey, M. J., and Reynolds, J. M.: 'Structure-fromMotion' photogrammetry: A low-cost, effective tool for geoscience applications, Geomorphology, 179, 300-314, https://doi.org/10.1016/j.geomorph.2012.08.021, 2012.

Zienert, A.: Die Würm-Vereisung und ihre Rückzugsstadien im Westteil des Hochschwarzwaldes, Z. Geomorphol., 17, 359-366, 1973. 


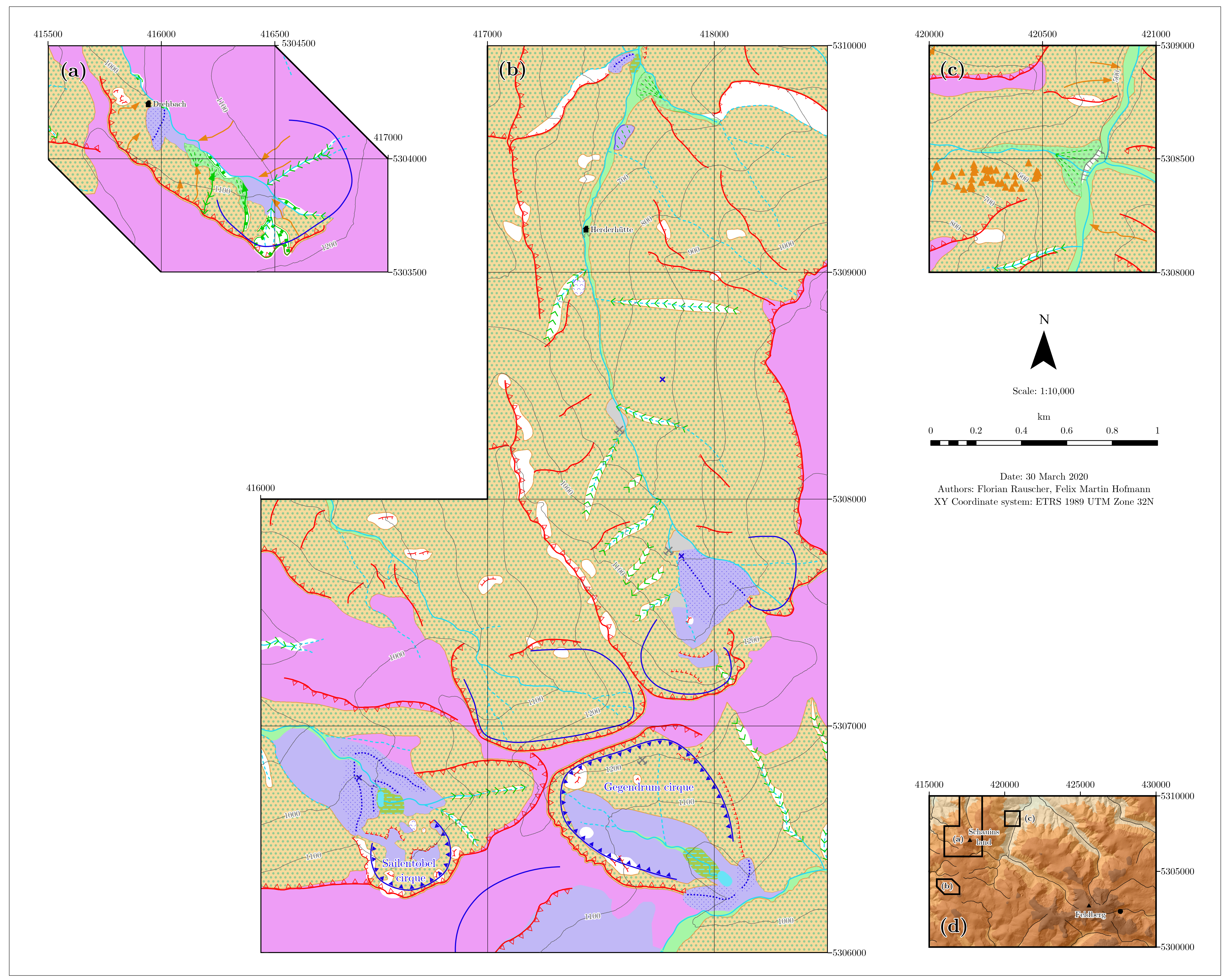

Figure S1. Geomorphological map of (a) Drehbach, (b) Kappeler Tal, the Sailendobel cirque and the Gegendrum cirque and of the entrance to (c) Hörnegrund. The legend of the geomorphological maps is given in Figure S4. The location of the mapped areas is shown in (d). The legend for (d) is given in Figure 2. 


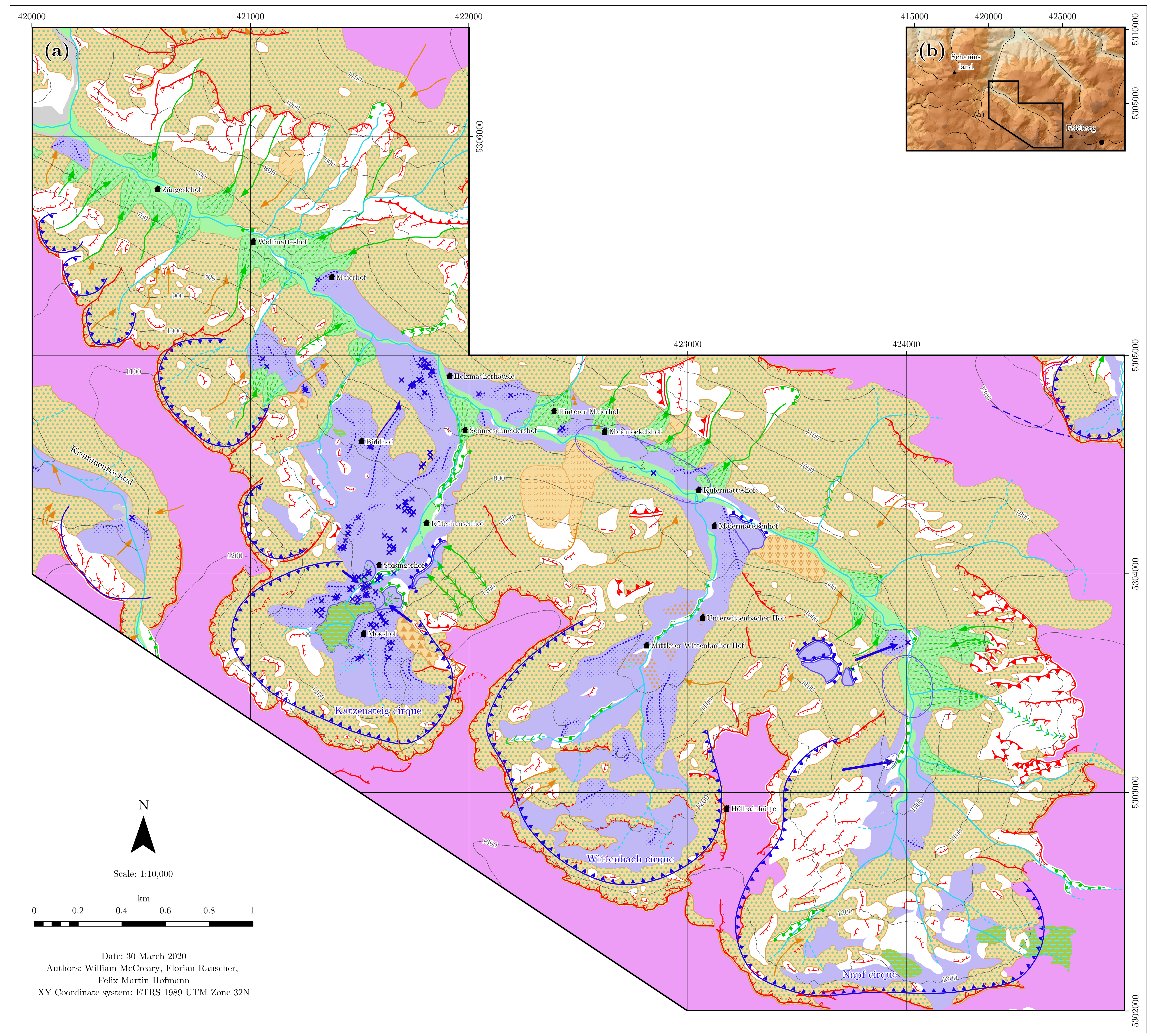

Fig. S2: Geomorphological map of (a) Sankt Wilhelmer Tal including the Katzensteig, Wittenbach and Napf cirques as well as of Krummenbachtal. The legend of the geomorphological maps is given in Figure S4. See (b) for the location of the mapped area. The legend for (b) is given in Figure 2. 


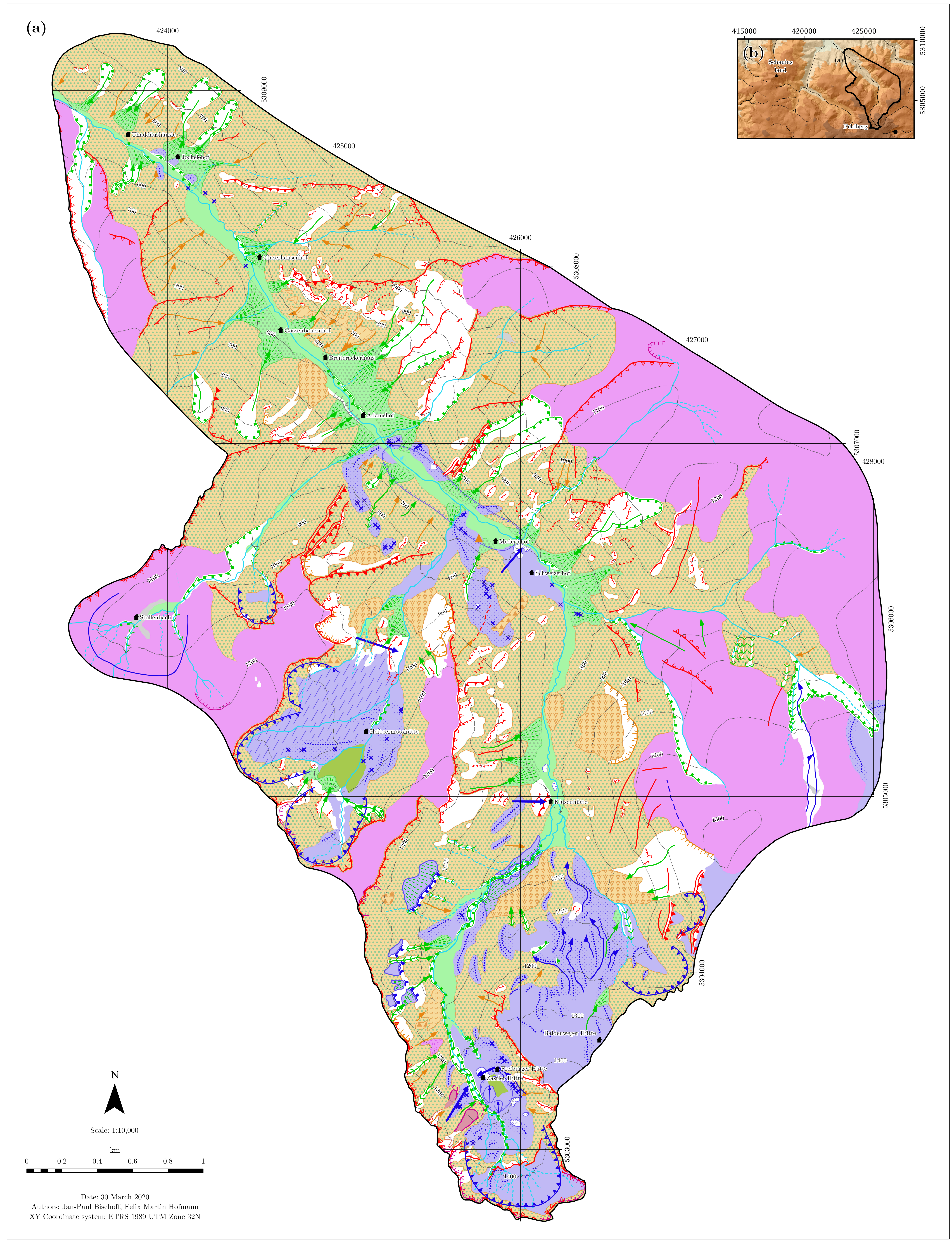

Fig. S3: Geomorphological map of (a) Zastler Tal and its tributary valleys. See (b) for the location of the mapped area. See Figure S4 for the legend of the geomorphological maps. The legend for (b) is given in Figure 2. 


\section{Structural landforms}

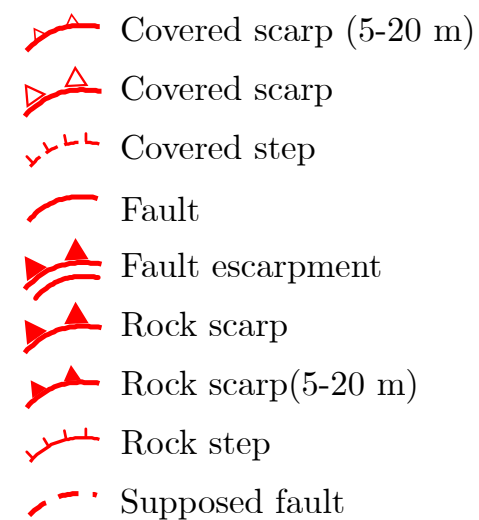

\section{Hydrography}

-- Intermittent stream

Stream

=- Marsh

Lake

\section{Fluvial landforms}

,- Alluvial fan (direction)

Debris flow

- Erosion or terrace edge $>5 \mathrm{~m}$

,- Glaciofluvial terrace (direction)

L $<$ Gully

Fluvial accumulation area

c3 Vegetation-covered alluvial fan

\section{Gravitational landforms}

$\Delta \quad$ Fallen boulder

Debris channel

YIS Scar

(13) Screes lope/talus slope

C3 Rockfall deposit

03 Landslide

Q3 Rockslide with dislocation

C3 Vegetation-covered scree

\section{Glacial landforms}

X Errratic boulder

$\bigcirc$ Glacial cirque (poorly developed)

En Glacial cirque

- Kame terrace (edge)

$\rightarrow$ Glacial meltwater channel

$\therefore$ Moraine crest

$\rightarrow \leftarrow$ Riegel
- Trimline

Drumlin

Overprinted moraine

Glacial basin

Glacial deposition area/till plain

3 Glaciofluvial deposition area

$\because \quad$ Moraine

$\approx$ Roches moutonnées

-- Streamlined till plain

\section{Periglacial landforms}

Periglacial deposition area (periglacial cover beds)

o3 Solifluction lobe

\section{Nival landforms}

$$
\begin{aligned}
& \text { Avalanche deposit } \\
& \text { Avalanche impact zone } \\
& \text { N3 Avalanche erosion zone } \\
& \text { Nival deposition area }
\end{aligned}
$$

\section{Other landforms}

× Mine

1ل Slope (backfilled or excavated)

Anthropic deposition area

Mire

\section{Other objects}

- Hamlet, farm or hut

Contour line (m a.s.l.), interval: $100 \mathrm{~m}$

Figure S4. Legend of the geomorphological maps of the Schauinsland area (Fig. S1), Sankt Wilhelmer Tal (Fig. S2) and of Zastler Tal (Fig. S3). 